\title{
Payment schemes for hydrological ecosystem services as a political instrument for the sustainable management of natural resources and poverty reduction - a case study from Belén, Nicaragua
}

\author{
J. Hack \\ Section of Engineering Hydrology and Water Management, Darmstadt, Germany \\ Received: 19 January 2010 - Revised: 7 June 2010 - Accepted: 9 June 2010 - Published: 25 August 2010
}

\begin{abstract}
The importance of intact ecosystems for humanwellbeing as well as the dependence on functions and services they provide is undoubted. But still neither the costs of ecosystem degradation nor the benefits from ecosystem functions and services appear on socio-economic balance sheets when development takes place. Consequently overuse of natural resources is socio-economically promoted by conventional resource management policies and external effects (externalities), equally positives and negatives, remain unregarded.

In this context the potential of payments for hydrological ecosystem services as a political instrument to foster sustainable natural resource use, and rural development shall be investigated. This paper introduces the principle concept of such payments, presents a case study from Nicaragua and highlights preliminary effects of the application of this instrument on natural resource use and development.
\end{abstract}

\section{Introduction}

Economic development often comes along with unceased exploitation of the natural environment, whereas the consumptive use of natural resources plays a special, even tragic role. Initially allowing a strong economic development, this unreflected resource use soon slows itself down due to increasing scarcity making further development more expensive or even impossible.

A possible way out of this dilemma promise to be payments for ecosystem services. Those payment schemes came about as market-based financing concepts, an alternative environmental protection policy to public or private subsidization for external costs. Within the international develop- ment cooperation payment schemes for ecosystem services are gaining additional popularity as a complementary policy for poverty reduction as well.

The implementation of these incentive-based payment schemes in Latin America has considerably increased recently (Mayrand and Paquin, 2004; Southgate and Wunder, 2007). While natural resource conservation is mainly the goal in the first place, a comparison of case studies in Latin America showed that of secondary order poverty alleviation may also be achievable (Pagiola et al., 2005). This paper presents first results of an application of the payment for ecosystem services concept within a Public-PrivatePartnership (PPP) project between the Deutsche Gesellschaft für Technische Zusammenarbeit (GTZ) GmbH (German agency for technical development cooperation), the municipality administration of Belén and the private sugar company, Compañía Azucarera del Sur (CASUR), in Nicaragua.

The investigation considers the payment for hydrological ecosystem services concept with regard to its potential to promote:

- sustainable environmental conservation and protection, i.e. reestablishment of the natural capital and its ecological function,

- poverty reduction, and

- participatory Integrated Land and Water Resource Management (IWRM) as part of a more sustainable spatial planning progress.

In the following the concept of payments for ecosystem services is introduced, then the application of this concept in the Gil González catchment and preliminary results from the pilot phase are presented.

The paper closes with a conclusion and outlook.

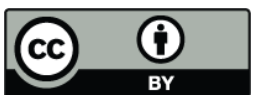

Correspondence to: J. Hack

(hack@ihwb.tu-darmstadt.de)

Published by Copernicus Publications on behalf of the European Geosciences Union. 
Land use options with respective benefits and external costs

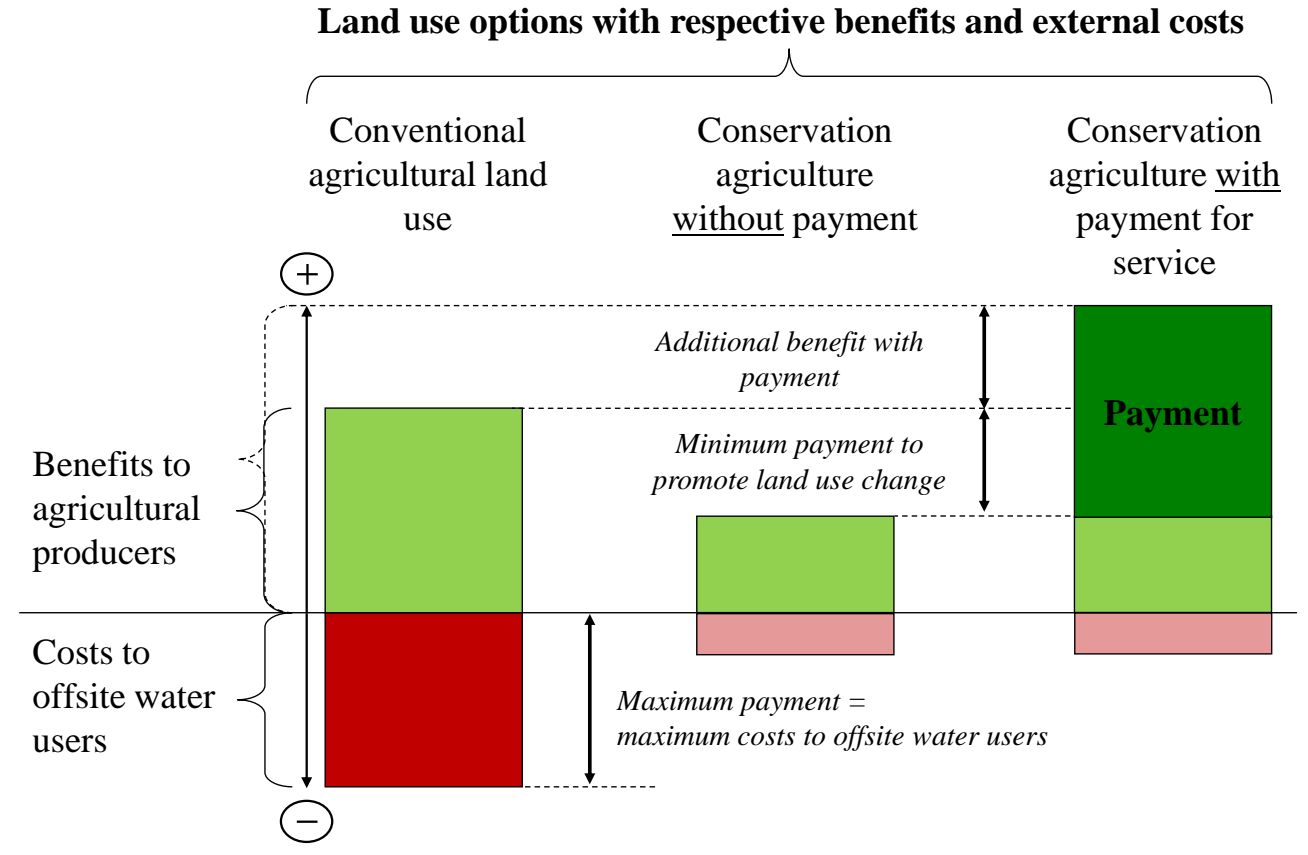

Fig. 1. Theoretical illustration of the overall benefits from an ecosystem service payment scheme compared to conventional agricultural land use and conservation agriculture without payment.

\section{Payments for hydrological ecosystem services}

In general agricultural land use causes external effects in form of alternations of ecosystem service provision. In the case of hydrological ecosystem service provision these alternations may affect the quantity and timing (e.g. dry season flow, peak flow) of the service as well as its quality.

While agricultural land use produces benefits on site, it often produces costs or harms to water users downstream (off site). Since these downstream costs have no impact on the benefits from the agricultural land use, an incentive to improve the hydrological services provision is lacking. In many cases the land user is not liable for the damage he causes by external effects. In case of a liability by law the land users benefits are reduced and in the worst case, if the land user does not take action to mitigate external effects, without even reaching the goal of damage reduction to downstream water users.

This kind of problem Coase considered as "The problem of social cost" (Coase, 1960). He stressed that the conventional political instrument, the Pigovian tax, to address negative externalities does not consider the total economic costs or benefits. In Coase' argumentation externalities behave reciprocal and the Pigovian tax does not produce incentives to improve the overall economic system.

In the context of the payment concept for hydrological ecosystem services the service provider receives a payment from a user of the service for changing his land use in order to improve the service provision. The service for which is paid for needs to be clearly defined and a continuous payment secured. This market-based concept of voluntary transactions is intended to produce incentives to land users to apply natural resource management practices, that are expected to result in continued or improved service provision, so a specific user or society will benefit more broadly.

The different on site and off site costs or benefits of the payment scheme in comparison to conventional environmental protection is illustrated in Fig. 1.

In the context of development cooperation the payment for ecosystem service concept raises hopes in achieving synergies with poverty reduction and integrated resource management aims as well.

\section{Application of the payment instrument in the Gil González catchment}

The use of market-based incentives to improve natural resource management in Nicaragua is still in a pilot state, but the federal government is encouraging the application of these political instruments and has included them as a possible management tool in its recently issued National Water Law (El Presidente de la República de Nicaragua, 2007). Although institutional roles to put the law in action are still undefined this indicates a first political statement. Furthermore the law paves the way for a (partly) decentralized and integrated enabling environment in order to manage water resources basin wide. 


\subsection{The payment for hydrological ecosystem services project in the Gil González catchment}

The Gil González catchment is located in the southwest of Nicaragua forming part of the Rio San Juan Basin, the largest basin of Nicaragua. The Gil González flows from west to east with a length of about $25 \mathrm{~km}$ until it empties, after passing through the Nocarime Lagoon, into the Lake of Nicaragua, the greatest freshwater reservoir of Central America.

With 60 habitants per $\mathrm{km}^{2}$ the catchment has a moderately high population density. While the lower part of the catchment is more densely populated and agricultural production is more intensive, the upper part of the catchment is characterized by dispersed settlements, few infrastructural development and predominantly subsistence agriculture.

In the last decades large parts of the upper catchment have been deforested due to agricultural expansion and the need for wood for construction and cooking. Empirical data indicates that this land use change has lead to decreased river discharge, especially in the dry season from November until April, and deterioration of the rivers water quality. Apart from ecological this has also lead to economic consequences for the downstream water users, particularly to the privately owned sugar company CASUR. The company cultivates sugarcane on $54 \mathrm{~km}^{2}$ along the shore of the Lake of Nicaragua from which it produces sugar, molasses and energy. It is the biggest water user of the region. $10 \mathrm{~km}^{2}$ of the total cultivation area are located within the lower part of the Gil González catchment. About half of the sugar production is exported (2008). With 1600 direct and several thousand indirect employees the company is also an important employer for the region.

The sugarcane production is strongly dependent on the water available for irrigation during the dry season. The increasing scarcity of inland water resources, decreasing river flow as well as lowering groundwater tables, and decreasing water quality (CIRA, 2007) convinced the company to invest in the upper part of the Gil González catchment to improve the hydrological service provision. This investment resulted in the establishment of a payment for hydrological ecosystem services concept as a Public-Private-Partnership (PPP) project between the Deutsche Gesellschaft für Technische Zusammenarbeit (GTZ) GmbH (German agency for technical development cooperation), the municipality administration of Belén and the private sugar company CASUR in Nicaragua. The main goals of this project are:

- to reforest 800 ha in the upper catchment area,

- to establish clearly defined protection and cultivation zones by identifying critical areas for service provision, and

- to generate alternative sources of income for rural population in the upper catchment.

\subsection{Description of institutional framework}

The realization of the payment scheme requires an institutional framework which regulates and supervises the transactions between service provider and service buyer. To allow a participative decision making regarding the design of the payment scheme and the definition of measures to improve the service provision, all stakeholders need to be equally represented within the institutional framework. Therefore the established institutional framework, consisting of a managing committee, a technical committee, and a coordination unit, includes representatives of the service providers (land user of the upper catchment), the service buyer (CASUR), the local municipality administration, the German development cooperation and technicians from several federal ministries for advisory purposes concerning the effectiveness of protective measures.

Figure 2 illustrates the projects institutional framework, the composition of all parts of the framework and their respective responsibilities.

\subsection{Description of the payment scheme}

The payment is not directly executed, but intermediate via the managing committee. The service buyer, at the moment only the sugar company, pays annually a fix amount for the use of the service into a project fund, managed by the managing committee. Participating service providers receive an annual payment for taking their formerly cultivated land out of production and reforestation. Most of the land now under protection/reforestation was formerly used for either pasture for cattle or cultivation of maize, beans or rice. In one case forested land was included as well in order to protect it. The payment scheme is shown in Fig. 3.

At the moment 200 ha are included in the project and for the improved service provision is paid for. The payment amount is about 35 US- $\$$ per hectare and year without distinguishing the former use of the land. An average rent was used to define the initial payment amount since there has not been a market so far for hydrological ecosystem services and thus no prices either.

\subsection{Methodology and data base}

The investigation objectives require an interdisciplinary approach using data sets from different disciplines. Regarding the socio-economic consideration of the possibility to internalize the negative external effects of the upstream land use the challenge is to find a way to properly valuate in economic terms the provision of the hydrological ecosystem service.

This valuation has to take place within the margin of willingness to pay of the service buyer (maximum payment or damage equivalent) and the possible loss compensation from a changed land use acting as a sufficient incentive to the service provider (minimum payment). This payment margin is 


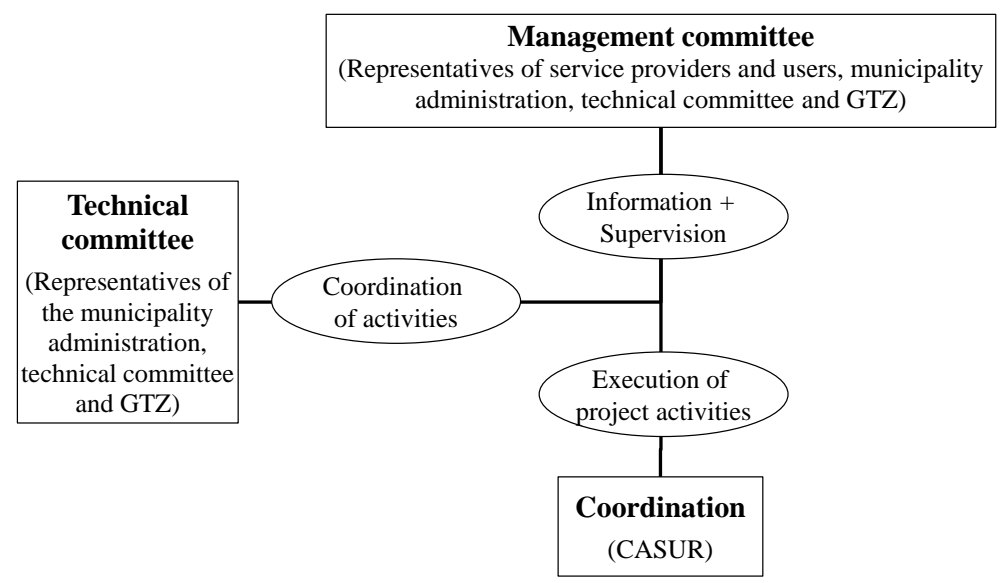

Fig. 2. Institutional framework supporting the payment scheme.

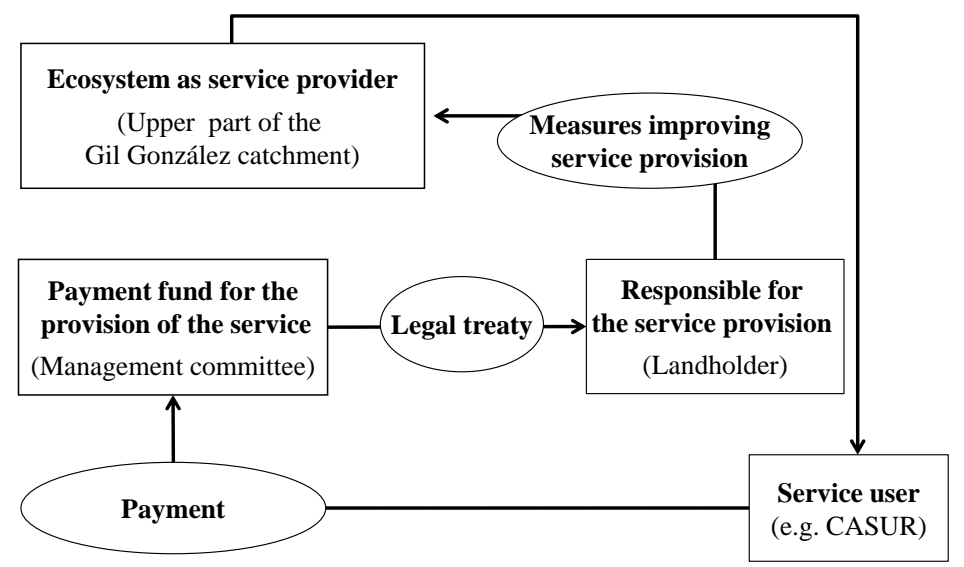

Fig. 3. Payment scheme of the Gil González catchment.

illustrated in Fig. 1. Both groups, service providers as well as service buyers, may have very heterogeneous economic situations influencing their willingness (or ability) to pay and their acceptance of incentives. The investigation of this aspect will be based on national census data before (INIDE, 2007) and after the establishment of the payment scheme and survey data. Preliminary results of a first survey realized in 2009 (see Table 2) and census data from 2005 provide qualitative information on the acceptance, impact on the economic situation, willingness to pay for the service provision and acceptance of the incentive (payment).

For the management and policy consideration it is to prove whether the established institutional framework in combination with the (national and/or regional) legal framework support an integrated and participatory management of water resources acting as an enabling environment for a sustainable development based on the natural resource capital. This requires an assessment of all actors and institutions including their roles and interactions.
A crucial point for acceptance of the payment concept is a good understanding and communication of physical, respectively hydrological, relationships in the catchment. Therefore hydrological modeling of different land use scenarios is necessary to identify their influence on hydrological service provision and income generation. This hydrological consideration is strongly correlated by several feedbacks with the above mentioned considerations.

From a quantitative point of view there is several data for hydrological modeling available, this is especially true in the case of precipitation data ( 6 stations with daily records with a distance of less than $20 \mathrm{~km}$ from the catchment), climatological data (3 stations with daily records of temperature, wind speed, humidity, air pressure, insolation with a distance of less than $30 \mathrm{~km}$ from the catchment), soil and land use data from recent field surveys (Acuña et al., 2008a,b,c; Rodríguez et al., 2003a,b). Additionally there are some measurements of river discharge and groundwater tables from recent years.

A summary of the available data and its temporal and spatial resolution is given in Table 1 . 
Table 1. Geophysical and socio-economic data base.

\begin{tabular}{lll}
\hline Data & Temporal resolution & Spatial resolution \\
\hline Precipitation & $1958-2008$ (daily) & $<20 \mathrm{~km}$ from the catchment \\
Climate & $1999-2007$ (daily) & $<30 \mathrm{~km}$ from the catchment \\
River discharge & $1965,2006,2008-2009$ (monthly) & every $5 \mathrm{~km}$ along main channel \\
Soil & $2002,2006,2008$ & field survey data \\
Vegetation and land use & 2004,2008 & field survey data \\
Hydrogeology & 2006 (single) & 3 wells in the catchment \\
Potable water production & $2003-2008$ & lower catchment \\
Census & 2005 & village \\
\hline
\end{tabular}

\section{Preliminary results}

In the following first result from the pilot phase of the project are summarized. The three project objectives: promotion of sustainable environmental protection, poverty reduction and promotion of participatory and integrated water resources management are presented separately. The results are based on two field surveys in the beginning and end of 2009.

\subsection{Promotion of sustainable environmental protection}

The assessment of the potential of the payment for hydrological ecosystem services concept to promote environmental protection requires a comparison with other environmental policy instruments formerly applied. In this context a few improvements regarding the promotion of environmental protection can be observed. Because the protection of the environment due to improvements of service provision is gaining regional importance economically the issue appears now more clearly on the local political agenda. Different stakeholders, from the public and private sector, are sensitized for the issue. As recent survey results show participants as well as non-participants of the payment scheme recognize environmental protection as a main objective of the payment concept. Land and water resources are increasingly regarded as "natural capital" that needs to be preserved.

Apart from these improvements in environmental perception and establishment of protected areas there still remain problems and challenges ahead. From the projected 800 ha only 200 ha are under protection and reforestation. Most of these areas are meadows, reforestation is advancing slowly, and the improvement of service provision is still in doubt. Additionally the focus of hydrological service provision is so far on water quantity, water quality aspects are not equally addressed.

\subsection{Impact on poverty reduction}

The establishment of the payment scheme as an additional source of income is considered by the beneficiaries generally as positive, although some beneficiaries regard the project
Table 2. Payment beneficiaries, respective area and total annual payment amount.

\begin{tabular}{lrrr}
\hline Community & Beneficiaries & $\begin{array}{c}\text { Area } \\
\text { [ha] }\end{array}$ & $\begin{array}{r}\text { Payment } \\
\text { [US \$] }\end{array}$ \\
\hline San Juan Viejo & 7 & 30.2 & 1057.4 \\
Las Mesas & 5 & 34.5 & 1206.5 \\
La Cruz & 1 & 3.5 & 121.3 \\
San Antonio & 3 & 3.9 & 136.2 \\
Mata de Caña & 12 & 36.2 & 1265.8 \\
\hline All & 28 & 108.2 & 3787.3 \\
Average & 6 & 21.6 & 757.4 \\
Min & 1 & 3.5 & 121.3 \\
Max & 12 & 36.2 & 1265.8 \\
\hline
\end{tabular}

solely as an environmental protection measure without economic importance to them. Positively attributed is that the payment is a secure and continuous income source over the negotiated contract period. Also positively considered are future benefits from reforestation on private land such as fruits, fuel wood and a general increase in value of the land. About half of the beneficiaries would include more of their land into the payment scheme, a quarter of all surveyed beneficiaries would continue reforestation even without payment.

In general the interest of participation in the project as a service provider is high. Problems with access to the payment scheme because of uncertain property titles and possible marginalization of non-participants were not expressed by the interviewees.

A considerable problem concerning the present payment amount is that it does not fully cover losses if land is completely taken out of production for reforestation. Furthermore new benefits from reforested land appear not until several months or years. The maintenance of areas in reforestation is regarded as labor intensive and without compensation.

The role of CASUR as single service buyer presently could turn out to be problematic as the payment amount could be controlled from the demand side. 


\subsection{Promotion of participatory and integrated water resources management}

A significant trend promoted by the implementation of the payment for hydrological ecosystem service concept is to consider water as a finite and vulnerable resource. It gains importance as an economic good in case of competition. With the establishment of an institutional framework consisting of representative of all stakeholder groups, development and management of water resources is starting to get more participatory following a cross-sectoral approach. The management committee may be a pilot form of a future catchment committee if its competencies could be expanded. At the moment it already plays an important role for spatial development planning through the establishment of protection and cultivation zones.

Compared to the designated institutional development (e.g. a National Water Authority responsible for the establishment of decentralized catchment committees) by the National Water Law the payment scheme seems to encourage this development faster and from the bottom up.

Another important impact of the payment scheme is the promotion of a dialog between up- and downstream land users, rural and urbanized habitants and different municipality administrations.

Despite these promising trends towards an integrated and participatory management and development of water resources there still remain obstacles for further advancement. The private sector represented by CASUR as single service buyer plays a very strong role in the institutional framework, in the design of the payment scheme as well as in the monitoring of the service provision. Although at the moment the company does not seem to take obviously advantage of this situation it poses a potential threat. This problem goes even farther when it comes to the assignment of roles for the private and public sector. The payment for ecosystem service concept is in the first place a market-based instrument, but the practice shows that the public policy is very essential for implementation and continuity. Different participants of the payment scheme expressed a need for stronger involvement of the public sector.

\section{Conclusions and outlook}

The projects pilot phase could successfully initiate the payment scheme including the establishment of an institutional framework. Of essential importance for this successful start was the disposition of a service buyer to invest in the sustainable provision of an ecosystem service that appeared to deteriorate and on which strongly depends his business on. The improvement of the public image of the company for its engagement in the project was also influencing its decision.

On the other side a multitude of land users in the upper part of the catchment were willing to change their land use in order to comply with the service provision requirements. A certain awareness for the importance to act by mitigating the present environmental problem, that was originally caused by a collective action of themselves, encouraged their participation although the payment does not fully compensate for losses. The acceptance of the project within the local population is high and participation in the planning and management process of the project is given. Generally speaking for the present payment scheme improvements in environmental protection, i.e. reforestation, and organizing the management of natural resources in an integrated and participatory manner are achieved more easily than improvements in additional incomes for the rural poor.

For achieving sustainability of the project several issues need to be addressed. In order to guarantee a continuous payment and an extension of the payment fund additional service users have to be integrated. This expansion process should support the assignment of a "right" price for the service provision and thus create a market for them. The strong institutional engagement of the public sector has to accompany this market creation by shaping the legal framework further. A crucial precondition is also an improvement in understanding and communication of cause and effect relationships between different land uses and water availability/quality (e.g. valuation of temporal and spatial service provision).

As additional service buyers come into consideration the downstream water supply company as well as commercial agriculturists of banana and vegetables. Their ability to pay may differ from that of the sugar company and has to be considered along with possible effects on end users of their products. In case of the water supply company the local water charge may increase (financial overloading of poor water users/service buyers since water has to be to a certain extent considered as a basic good). The integration of additional water users in the project hold the possibility for conflict resolution, because former competitive water users could share common interest as service buyers and this may open spaces for additional bargains and water saving strategies.

On the supply side the option of service provision has to become a serious alternative to unsustainable (agricultural) land use by increasing its economic importance. If the payment amount can be raised in the future is doubtful. There may be the possibility to raise the payment amount in a limited way by the reduction of transaction costs in the long run. A more feasible way could be to look for synergies between certain agricultural (e.g. agroforestry) and non-agricultural (e.g. rural tourism) practices and the provision of hydrological services so that an income complementary to the payment can be achieved. In this context it is also important to find a way to generate as well complementary income in the short term and to take non-monetary benefits (i.e. compensations) into account. These synergies could also represent a viable strategy to establish alternative or additional development perspectives for rural communities and reduce the risk of creating perverse incentives (e.g. receiving payments for land use change that already is forced by law). 
To support the above mentioned next steps a combined hydrological and socio-economic modeling will be carried out thoroughly. While a rainfall-run-off model will be used to analyze physical influence of different land use to hydrological ecosystem service provision, a socio-economic model complements potential development perspectives. The identification of critical areas for future service provision considering spatial and temporal service provision will be of special importance.

Acknowledgements. The Project "Payments for hydrological Ecosystem Services in the Gil González Catchment" is carried out by the Gesellschaft für Technische Zusammenarbeit (GTZ) as part of the National Program "Sustainable Natural Resource Management and Formation of entrepreneurial Capacities". I wish to thank all colleagues of the GTZ as well as the project team at CASUR for an intensive cooperation, support and the supply of all necessary data.

Edited by: A. Wahren, F. Tavares Wahren, and K.-H. Feger

Reviewed by: two anonymous referees

\section{References}

Acuña, E., Aguirre, C., and Zelaya, C.: Suelos, Capacidad de Uso de la Tierra y Conflictos de Uso en el Municipio Belén, Tech. rep., Asociación de Municipios de Rivas (AMUR), Alcaldia Municipal de Belén, 2008a.

Acuña, E., Aguirre, C., and Zelaya, C.: Suelos, Capacidad de Uso de la Tierra y Conflictos de Uso en el Municipio Potosí, Tech. rep., Asociación de Municipios de Rivas (AMUR), Alcaldia Municipal de Potosí, 2008b.

Acuña, E., Aguirre, C., and Zelaya, C.: Suelos, Capacidad de Uso de la Tierra y Conflictos de Uso en el Municipio Buenos Aires, Tech. rep., Asociación de Municipios de Rivas (AMUR), Alcaldia Municipal de Buenos Aires, 2008c.
CIRA: Calidad y Disponibilidad del Agua de la subcuenca del Río Gil González en el área de influencia Municipal de Belén y Potosí: Un aporte de información científico-técnica para el desarrollo de una estrategia de gestión integral, Centro de Investigación de Recursos Acuaticos, 2007.

Coase, R. H.: The Problem of Social Cost, J. Law Econ., 3, p. 1, doi:10.1086/466560, available at: http://www.journals. uchicago.edu/doi/abs/10.1086/466560 (last access: 13 August 2010), 1960.

El Presidente de la República de Nicaragua: Ley General de Aguas Nacionales, Ley No. 620 - La Gaceta No. 169, 2007.

INIDE: VIII censo de población y IV de vivienda, censo 2005, República de Nicaragua, Instituto Nacional de Estadísticas y Censos, Managua, 2007.

Mayrand, K. and Paquin, M.: Payments for Environmental Services: A Survey and Assessment of Current Schemes, Unisféra International Centre, Montreal, available at: http:// www.cec.org/files/PDF/ECONOMY/PES-Unisfera_en.pdf (last access: 13 August 2010), 2004.

Pagiola, S., Arcenas, A., and Platais, G.: Can Payments for Environmental Services Help Reduce Poverty? An Exploration of the Issues and the Evidence to Date from Latin America, World Development, 33, 237-253, 2005.

Rodríguez, I., Aguirre, C., and Mendoza, B.: Actualización del estado del recurso suelo y capacidad de uso de la tierra del municipio Belén, Tech. rep., Universidad Nacional Agraria (UNA) Facultad de Recursos Naturales y del Ambiente - Departamento de Manejo de Cuencas y Gestión Ambiental, 2003a.

Rodríguez, I., Aguirre, C., and Mendoza, B.: Estado de los Suelos y Capacidad de Uso de la Tierra en el municipio Belén, Tech. rep., UNA - Facultad de Recursos Naturales y del Ambiente - Departamento de Manejo de Cuencas y Gestión Ambiental, 2003b.

Southgate, D. and Wunder, S.: Paying for Watershed Services in Latin America: A Review of Current Initiatives, Office of International Research, Education, and Development, 07, 2007. 